\title{
Chamaemelum nobile Flower Oil
}

National Cancer Institute

\section{Source}

National Cancer Institute. Chamaemelum nobile Flower Oil. NCI Thesaurus. Code C107285.

The oil extracted from the petals of Chamaemelum nobile. Chamomile oil has antiinflammatory properties. 